\title{
The Effect of Corporate Social Responsibility Disclosure on Financial Performance: Evidence from Credit Institutions in Vietnam
}

\author{
Nguyen Bich Ngoc ${ }^{1}$ \\ ${ }^{1}$ Banking Academy of Vietnam, Vietnam \\ Correspondence: Nguyen Bich Ngoc. E-mail: ngocnb@hvnh.edu.vn
}

Received: February 7, 2018

Accepted: February 28, 2018

Online Published: March 20, 2018

doi:10.5539/ass.v14n4p109

URL: https://doi.org/10.5539/ass.v14n4p109

\begin{abstract}
This study examines the relationship between corporate social responsibility (CSR) disclosure and financial performance of banks in Vietnam over the period 2011 - 2016. By using content analysis to approach CSR related data as well as ordinary least square (OLS) estimator to analyse data, the finding of this study indicates that there is a significant negative relationship between CSR disclosure and financial performance of commercial banks in Vietnam. This result might be explained by additional requirements of the law for social responsibility while banks are in difficult situation as a result of economic slowdown during researched period. Together with that, perception of banks' customers toward banking corporate social responsibility of Vietnam also contributed to build up this negative linkage.
\end{abstract}

Keywords: corporate social responsibility, corporate social performance, financial performance, Credit institution, Bank

\section{Introduction}

It is about eighty five years from the day when Professor Dodd had looked at the relationship between corporate social responsibility and financial performance (Dodd, 1932) which untill now still has been an interest and controversial topic to researchers. While scholars confirming 'trade-off hypothesis' show that joining CSR practices might make firms undermine the main object of the company which is according to Friedman (1970) is maximising profit; corporate social responsibility of firms is stressed by supporters of 'social impact hypothesis', who indicate that by satisfying the needs of different group of stakeholders, firms can achieve greater effectiveness and efficiency and therefore enhance their financial performance. Discussing about this problem, there are many researchers have studied the effect of corporate social responsibility on financial performance, but the results are mixed.

Particularly, Preston and O'Bannon (1997); Hillman, Kein and Luce (2001); Adeneye and Ahmed (2015) and Grigoris Giannarakis, George Konteos, Eleni Zafeiriou and Xanthi Partalidou (2016) support the idea that CSR disclosure index has positive impact on firm's financial performance because social responsibility is considered as firm's shield against negative information damaging firm's reputation, and therefore protect financial result of firm (Soana, 2011). Besides by disclosing CSR, firms can attract more customers and quality employees (Greening and Turban, 2000) as well as strengthen relationship with stakeholders to fund for their sustainable operation (Moskowitz, 1972).

By contrast, Brammer, Brooks and Pavelin (2006) and Surroca and Tribó (2008) proved negative corporate social responsibility - financial performance linkage because applying CSR might make firms suffer competitive disadvantage (Cochran, Carroll \& Hatfield, 1985; Jensen, 2002) and therefore reduce firm's profitaility. Besides, no correlation between CSR disclosure and financal performance was witnessed in studies conducted by McWilliams and Siegel (2000); Mahoney and Roberts (2007) and Makni, Francoeur and Bellavance (2009). The lack of existence of this relationship according to Ullmann (1985) is because it is affected by many factors or variables that if a linkage existed, it is difficult to be detected due to the problems associated with measurement in empirical studies.

Yet in spite of long record of article about the relationship between corporate social responsibility and financial performance, most of them analyse data of firms in developed countries in where the concept of CSR first emerged (Belal, 2001). However, through the time Crane, Matten and Spence (2008) prove that as the result of 
globalisation and the increase in number of multinational corporations operating in developing countries, CSR standard has become one of requirements in business in less developed countries in general and in Vietnam in particular. According to Institute of Labour Science and Social Affairs of Vietnam (2011), corporate social responsibility is defined as follows:

"It is the voluntariness of enterprise in committing to comply with the regulations of labor, environment, and business activities basing on national laws, international general rules, and ensure the harmonious benefit of parties, together with sustainable development of national socio -economic."

Although CSR has been clearly defined as well as there is projects aiming to support SMEs in Vietnam in CSR implementation, the proportion of companies that understood CSR concept was low, only at 20\% (UNIDO, 2010). Moreover, studies focusing on accessing the corporate social responsibility and financial performance linkage in conventional banking sector, which has been increasingly involved with financing economic activity aiming at sustainable development and offering microcredit to the poor, are also limited. Therefore, this study wants to address this gap by conducting a research based on sample of commercial banks in Vietnam.

The rest of this paper is structured as follows. Section 2 provides literature on the impact of corporate social responsibility on financial performance. Section 3 looks at methods used to collect and analyse data. Section 4 will report and discuss the results from analysis, models and findings. The last section will summarise main findings of this study.

\section{Literature Review}

In 1997, Preston and O'Bannon did a research on the link between three dimensions on CSR (community and environmental responsibility; ability to select and retain good people and quality of products and services) and financial performance (ROA; ROE and ROI) of 67 large corporations in US from 1982 to 1992. The positive relationship was found by authors who showed that positive synergies or available funding might be the best explanation for this linkage. Fortune corporate index, which is used by Preston and O'Bannon, was applied again as a variable to measure corporate social performance in research conducted by Stanwick and Stanwick (1998) but for the period from 1987 to 1992 . The result of regression analysis also supports the idea that there is positive relationship between corporate social performance and firm's financial performance.

To be considered as "a measure of overall management of a firm rather than being specific to CSP" (Waddock \& Graves, 1997), Fortune corporate index was not used as proxy for CSR disclosure in study made by Waddock and Graves. KLD rating scheme developed by Kinder, Lydenberg, Domini and Co., Inc (Griffin and Mahon, 1997) and to be recognized as the best index available for researchers working on corporate social responsibility in the United State (Hillman, Kein \& Luce, 2001) was used instead. However, findings of this research also support for researchers using Fortune corporate index that there is positive linkage between corporate social responsibility and financial performance of most S\&P 500 firms. More importantly, authors agree with Preston and O'Bannon (1997) that there is a tension exists between explicit costs and implicit costs of the firms, leading firms have to adopt CSR practices to improve their financial performance.

Recently, the United State companies again was used as samples in research about the impact of CSR on financial performance conducted by Grigoris Giannarakis, George Konteos, Eleni Zafeiriou and Xanthi Partalidou (2016). The result also supports findings of previous researchers that the higher CSR disclosure score is, the greater financial performance company can has.

Positive relationship between CSR and financial performance also was witnessed in study conducted by Adeneye and Ahmed (2015) who used bivariate and multivariate analysis to analyse data of 500 firms in the United Kingdom. As a result of that, authors recommended that UK' firms should make more efforts to carry out their corporate social responsibilities if they want to increase their financial performance.

While studies above were done in developed markets, in where researchers can use reputation indices compiled by specialised rating agencies such as Fortune corporate index and KLD ratings to measure firm's CSR, researches conducted in developing countries often use content analysis to approach CSR. Particularly, also analysing the link between CSR and financial performance but focusing in Vietnam, Trang and Yekini (2014) followed the approach adopted by studies in developing countries such as Chen and Wang (2011), who used annual report to collect data on firm's CSR practices and disclosure. Besides, multivariate regression was used and showed that by disclosing corporate social responsibility, firms can obtain benefits and enhance sustainable development. This finding is supported by Nguyen, Tran, Le, Nguyen, Trinh and Le (2015), who indicated that financial performance or firms in Vietnam will be positively affected by CSR disclosure in previous year. More importantly, information relating to environment practice was found to have positive relationship with firm value, 
which might be explained by greater public awareness about pollution after many environmental scandals such as the Vedan incident and the Formusa incident happened in Vietnam.

Not like studies mentioned above which used samples from multiple industries, which might affect the accuracy of CSR score as each industry has it own characteristics leading to the nature of CSR unique (Griffin anf Mahon 1997), Simpson and Kohers (2002) entirely focus on banking industry. By using Community Reinvestment Act ratings as bank' social performance measure and ROE as proxy for financial performance, the regression analysis supported positive corporate social performance - financial performance. However, Simpson and Kohers showed that the use of the CRA ratings as bank' social performance measure might not a broad and comprehensive measure of corporate social performance and need to be improved in the future.

Did not provide solution for limitation in research conducted by Simpson and Kohers (2002) but used another method (content analysis) for measuring CSR disclosure index of 17 Islamic banks in Malaysia from 2008 to 2010, Arshad, Othman and Othman (2012) came to conclusion that CSR practices positively related to reputation and performance of banks. Particularly, results of the multiple regression analysis showed that bank's CSR disclosure index significantly and positively affect ROA and ROE, which according to authors is because bank's managers realize that they can strengthen relationship with stakeholders to achieve economic sustainability for banks through CSR practices. The same method was applied in research did by Platonova, Asutay, Dixon and Mohammad (2016) for Islamic bank from 2000 to 2014 and the same result was witnessed. This finding, according to authors is because good CSR practices might built up greater reputation for banks, which after that help banks to increase their customer loyalty as well as attract support from wider range of stakeholders, and finally improve their financial performance.

On the contrary, some researchers pointed that applying social responsibility increases firm's cost and therefore reduce profitability. In particular, by drawing database from The Ethical Investment Research Service (EIRIS) which is specializes in the measurement of corporate social performance, Brammer, Brooks and Pavelin (2006) showed that, for a sample of UK quoted companies, the higher social performance firm have, the lower returns it achieve.

Testing the relationship between the implementation of socially responsible and financial performance with a sample of 358 companies, from 22 different countries, for the period 2002- 2005, Surroca and Tribó (2008) supported finding of Brammer, Brooks and Pavelin (2006). More importantly, result of cross-country analysis stressed that negative relationship is more pronounced in countries with less efficient financial markets but more developed internal corporate control mechanisms. This is because in such country, managers can take advantage of that inefficiency and invest more money in socially responsible activities than necessary in order to complement an entrenchment strategy.

Doing studies in China in where many mineral enterprise were closed as a result of their environmental pollution, Pan, Sha, Zhang and Ke (2014) indicated that in a highly polluting industry, environment responsibility negatively impact on firm's profit, which is according to authors is because a lot of money was allocated for decreasing environmental impacts, leading to decrease in profit. This result however, contradict to finding in research conducted by Nguyen, Tran, Le, Nguyen, Trinh and Le (2015) as mentioned above.

Interestingly, also doing research on the relationship between pollution disclosures by firms in highly polluting industries and firms' financial performance like Pan, Sha, Zhang and Ke (2014) and Nguyen, Tran, Le, Nguyen, Trinh and Le (2015), but Jaggi and Freedman (1982) found no correlation. In particular, the enforcement of disclosing of pollution information as one requirement of the National Environmental Policy Act of 1969 attracted attention of both firm' managers, investors and researchers including Freedman and Jaggi. Authors indicated that there is no correlation, which was supported again in their later study (Freedman and Jaggi, 1986).

Mahoney and Roberts (2007) in a research on 300 Canadian firms from 1996 to 1999 also came to conclusion that there is no significant linkage between corporate social performance and financial performance. However, not like Freedman and Jaggi who only used single dimensional indicator, Mahoney and Roberts used Canadian Social Investment Database (CSID) ratings which evaluate Canadian firms' CSP across eight dimensions such as community, diversity, employee relations, international, product, business practices, and other. The result is consistence with findings of Makni, Francoeur and Bellavance (2009) who also applied the same CSR measurement method to study CSR-FP link of Canadian firms.

No statistically significant linkage between corporate social responsibility and ROA, ROE was also revealed in study of Brine, Brown and Hackett (2007) who used CSR data gathered from publicly available information and a confidential list provided by the Department of Environment and Water Resources and the Centre for Australian Ethical Research to measure firm's CSR. 
Proving equation estimated by Waddock and Graves (1997), who indicated positive relationship between CSR and firm financial performance as mentioned above, is misspecified as a result of not including a measure of firm level investment in R\&D, McWilliams and Siegel (2000) tested model again and came to conclusion that CSP has a neutral effect on profitability. This result according to McWilliams and Siegel is understandable because firms actively engaging in CSR also increase their investments in R\&D, leading to the assessment of the impact of CSR on firm performance might be difficult if R\&D is not controlled. Besides, no direct relationship between corporate responsibility and financial performance also was found when Surroca, Tribó and Waddock (2010) took the mediating effect of a firm's intangible resources in consideration.

Similar to Simpson and Kohers (2002), Arshad, Othman and Othman (2012) and Platonova, Asutay, Dixon and Mohammad (2016), Soana (2011) just only concentrate on doing research analysing CSR - financial performance relationship in banking sector. However, Soana showed that there is no statistically significant relationship between CSP and corporate financial performance, which is because Italian banks did not have to bear any sacrifice in term of financial performance to achieve success in directing investments and costs ethically as well as investment in CSR does not bring financial advantage to banks. This result is consistence with findings of Cheung and Mak (2010) and Tjia and Setiawati (2012).

Last but not least, nonlinear relationship between corporate social performance and financial performance were discovered. Particularly, Bowman and Haire (1975) found that lower financial performance was witnessed in firms having low and high CSR, whereas highest financial performance was witnessed in firms having mediocre CSR.

Wang, Choi and Li (2008) also confirmed the relationship between CSR and financial performance is non linear. To be more specific, authors showed that corporate philanthropy at the beginning might enable the firm to gain greater control over stakeholder resources and therefore enhances firm's financial performance. However, through the time agency costs and direct costs will become dominant when the amount of philanthropic contributions continues to increase.

Interestingly, later research conducted by Barnett and Salomon (2012) also confirmed non-linear relationship between CSR and financial performance, but in U-shape. In particular while firms with moderate CSP have lower CFP than firms with low CSP, highest CFP was witnessed in firms have high CSP.

Motivated by the works of Barnete and Salomon (2012), Nollet, Filis and Mitrokostas (2016) examined both the linear and non-linear linkage between corporate social performance and corporate financial performance but under the context of a new dataset which is Bloomberg's Environmental Social Governance (ESG) Disclosure score instead of normalized version of the KLD dataset used by Barnete and Salomon (2012). The research finding showed that only after CSR investments crossed a crucial point, it has positively impact a company's profitability. Therefore, managers should carefully consider the use of resources to take advantage of CSR investments to serve firm's profitability.

\section{Methodology}

The main aim of this research is to examine the effect of CSR disclosure on financial performance of Vietnamese commercial banks. However, there are many indicators can be used as proxy for banks' financial performance as well as CSR disclosure index. Therefore, in this section, detailed information about dependent, independent and control variables, and reason why variables are chosen will be presented.

In a research on the relationship between corporate social performance and corporate financial performance, Griffin and Mahon (1997) showed that there are up to 80 financial measures of financial performance in which accounting based measures such as return on assets (ROA) is considered as the most accurate in capturing the banks' financial performance (Simpson and Kohers, 2002). Besides, many researchers such as Bowman and Haire (1975); Aupperle, Carroll and Hatfield (1985); Preston and O'Bannon (1997); Trang and Yekini (2014); Taskin (2015) and Platonova, Asutay, Dixon and Mohammad (2016) also chose ROA as proxy for financial performance when doing research in this area. Therefore, this study also did use ROA (net income on average total assets) as proxy of financial performance of Vietnamese banks.

To be different from many researchers conducting researches in developed countries in where indicators of banks' corporate social performance are already available, this study scanned banks' annual reports and used content analysis method to assess the CSR disclosure. Particularly, to measure the level of corporate social responsibility information disclosed by Vietnamese banks, this study firstly classified the information revealed in annual report into four categories of items which are community involvement, environment, products and customers and human resources. These CSR themes were chosen based on professional experience of many researchers in this 
area such as Saleh (2009) and Akinpelu, Ogunbi, Olaniran and Ogunseye (2013). More importantly, these four main group for disclosure are totally applicable to the commercial banks in Vietnam. To be more specific, according to survey of Vietnamese managers' awareness of corporate social responsibility conducted by Hieu (2011), large proportion of managers thought that taking part in public welfare activities or community involvement, paying more money for improving working environment quality and employees' health as well as providing high quality products and services are the social responsibility of company. Besides, the findings of survey conducted by UNIDO in 2013 again stressed the importance in reporting human rights, labour practices, environment, consumer issues and community involvement in CSR report. Moreover, in a research on CSR disclosure of firms in Vietnam, Trang and Yekini (2014) also used environment, community, human resources or employees, and customer and production as four dimensions of CSR. In addition to that, the issue of Decisions and Directives related to promoting the green credit growth, saving and efficient using of energy, nature resources and environmental protection such as No.403/QD-TTg, Directive No.30/CT-TTg and Directive No.03/CT-NHNN by Government and State bank of Vietnam in recent years have highlighted the importance of environmental disclosure in CSR of banks. As a result of that, four themes which are community involvement, environment, products and customers and human resources were chosen to measure CSR disclosure index for banks in this study. These four themes comprise sub dimensions (appendix 1), which were designed based on practice of CSR among SMEs in Vietnam (UNIDO, 2013), perception of banks' managers and customers toward banking corporate social responsibility of Vietnam and previous experience of researchers doing study about corporate social responsibility reporting by commercial banks in developing countries, especially Lipunga (2013).

After that, researcher will detect the presence or absence of social responsibility information. If a bank in the sample make an item included in the categories, it received a score of 1 or 0 otherwise. These points awarded after that was divided by total number of selected dimensions to calculate corporate social responsibility index (Haniffa and Hudaib, 2007; Platonova, Asutay, Dixon and Mohammad, 2016).

$$
\text { CSR disclosure index }=\frac{\sum_{i=1}^{n}\left(X_{i j t}\right)}{N}
$$

Where:

$\mathrm{X}_{\mathrm{ijt}}$ is variable $\mathrm{X}(1, \ldots \mathrm{n})$ for dimension $\mathrm{j}$ and time $\mathrm{t}$

$\mathrm{N}$ is total number of selected dimensions

However, it is worth to notice that although content analysis has been used to measure CSR disclosure index of banks by many researchers such as Chen and Wang (2011); Arshad, Othman and Othman (2012); Trang and Yekini (2014) and Taskin (2015), the reliability and validity are still two problems need to be solved to ensure the accuracy of research data. Therefore, the method, which is cross-check is applied at the suggestion of Weber (1990). Particularly, following Platonova, Asutay, Dixon, and Mohammad (2016), four steps were taken. Firstly, a small scale trial, where $10 \%$ of sample examined or 17 annual reports were randomly selected, was conducted. Secondly, one month later, CSR disclosure index of these 17 annual reports was marked again to check the consistency of scoring system. Thirdly, two independent coders are required to calculate CSR disclosure index of 17 annual reports again after they did understand the meanings of the dimensions and sub-dimensions used. Fourthly, index of pilot tests and index measured by coders were compared to revise and define again before establishing final decision rules used to measure CSR disclosure index of banks.

Following previous empirical studies, control variables were also used in this study. Particularly, Huizinga, (2000); Athanasoglou, Brissimis and Delis (2008) and Bikker and Hu (2012) indicated that bank size did have impact on banks' financial performance as banks with large size might attract more capital at a lower prize leading to higher profits. Therefore, following other studies, bank size in the form of total assets is used as one of control variables in this research. Together with bank size, Kosmidou (2008) in a research about the determinants of banks' profits indicated that capital ratio or equity on average total assets (Simpson and Kohers, 2002) did have impact on banks' financial performance because higher capital ratio means lower cost of capital and therefore higher financial performance (Growe, DeBruine, Lee, Tudón Maldonado, 2014). This positive correlation also has been shown in many studies such as (Simpson and Kohers, 2002; García-Herrero, Gavilá and Santabárbara, 2009 and Francis, 2013). Therefore, in this study, capital ratio is also used as control. Besides, a number empirical studies consider the loans to total assets to be one of the determinants of banks' financial performance (Mamatzakis and Remoundos, 2003; Olson and Zoubi, 2011 and Trujillo-Ponce, 2013). To be more specific, Growe, DeBruine, Lee, Tudón Maldonado (2014) showed that in comparison with secure assets, loans might earn higher rates of return; therefore, bank with higher loans to total assets might get higher revenue. In 
addition to bank size, capital ratio and the loan ratio, the overhead expenses, which is presented by noninterest expenses to average total assets, is also considered as important factor in relationship between CSR disclosure and banks' financial performance (Staikouras and Wood, 2004 and Tan and Floros, 2012) and used in this study.

Table 1. Definition of variables

\begin{tabular}{cccc}
\hline Variable name & $\begin{array}{c}\text { Variable } \\
\text { abbreviation }\end{array}$ & Variable description & Variable type \\
\hline $\begin{array}{c}\text { Return on asset } \\
\text { Corporate social }\end{array}$ & ROA & Profit after tax/ total assets & Continuous variable \\
responsibility disclosure & CSRD & CSR disclosure index $=\frac{\sum_{i=1}\left(x_{i j t}\right)}{N} 1$ & Continuous variable \\
Bank size & LTA & Log of total assets & Continuous variable \\
Capital ratio & EA & Equity/average total assets & Continuous variable \\
Loan ratio & LA & Average total loans/average total assets & Continuous variable \\
Overhead expenses & NEA & Noninterest expenses/average total assets & Continuous variable \\
\hline
\end{tabular}

The data used in this study was downloaded from 31 official banks website and Bankscope which is the global database of banks. However, some of the examined banks do not have enough required annual report for the period in question (2011 - 2016) leading to missing data; therefore, the sample yielded 179 reports.

As data used in this study is numerical data, of which value can be measured numerically (Saunders, Lewis \& Thornhill, 2007), quantitative approach was applied to measure ROA, CSR disclosure level of Vietnamese banks, total asset, equity capital to average total assets, net loan to total asset of banks, overhead expenses as well as connections and relationships between variables.

Firstly, descriptives was used to explore basic statistics such as mean, maximum, minimum, standard deviation of variables. Besides, SPSS graph builder was also used to describe changes in mean value of ROA and CSR disclosure index through years.

Secondly, outliers and normality of the distribution are tested. To find out whether there is potential outliers in this study or not, tails of distribution presented in graph named histogram as a signal was used. After that, normality of the distribution will be accessed by Skewness and Kurtosis standards.

Thirdly, to make sure results of further tests in this study are accurate multicollinearity also will be tested (Field, 2009; Pallant, 2013). Particularly, to test the presence of autocorrelation which might lead to many problems such as estimators are biased and inefficient, results of $t$ and F-tests and $R^{2}$ are not reliable (Gujarati, 1999), this study used Durbin Watson d statistic.

Finally, results obtained from correlation matrix was used to test for multicollinearity.

After checking and correcting problems related to data, the next step is to construct model and run appropriate tests to find relationship between CSRD and banks' financial performance.

$$
\mathrm{ROA}=\beta_{0}+\beta_{1} * \mathrm{CSRD}+\beta_{2} * \mathrm{LTA}+\beta_{3} * \mathrm{EA}+\beta_{4} * \mathrm{LA}+\beta_{5} * \mathrm{NEA}+\varepsilon .
$$

Where:

ROA: return on asset.

LTA: natural logarithm of total assets.

EA: equity on average total assets.

LA: loans to total assets.

NEA: noninterest expenses on average total assets

$\beta_{0:}$ constant.

$\beta_{1-5}$ : slopes of independent variables.

$\varepsilon:$ random error.

This study used ordinary least square (OLS) estimator to estimate parameters because even in some estimating problems, OLS estimator still succeed on some of other criteria and it is also easy to compute (Kennedy, 2008). Besides, "it is intuitively appealing and mathematically much simpler" (Gujarati, 2003, p58) in comparison with other methods. More importantly, this method was also used by researchers in this field such as Simpson and Kohers (2002). 


\section{Results and Discussions}

An overview about statistical features of data through describing minimum, maximum values, means and standard deviation of all variables used was presented in table 2

Table 2. Descriptive statistics

\begin{tabular}{cccccc}
\hline \multicolumn{7}{c}{ Descriptive Statistics } \\
\hline NOA & N & Minimum & Maximum & Mean & Std. Deviation \\
\hline CSRD & 176 &, 0003 &, 0259 &, 008634 &, 0045865 \\
LTA & 179 &, 2200 &, 7073 &, 433604 &, 1408857 \\
EA & 176 & 8,8439 & 10,6572 & 9,775883 &, 4839295 \\
LA & 179 &, 0426 &, 2384 &, 095423 &, 0427529 \\
NEA & 179 &, 3044 &, 7238 &, 546984 &, 1321249 \\
Valid N (listwise) & 172 &, 0107 &, 058 &, 02327 &, 011787 \\
\hline
\end{tabular}

As can see from the descriptive statistics in table 2 above, for selected commercial banks, the highest and lowest value of return on total assets was $0,03 \%$ and $2,59 \%$ respectively indicating in general commercial banks can get earnings from invested capital in all years analysed. However, mean value of ROA is $0,86 \%$ which is lower than $1 \%$ - the proportion required by the Moody's to have good financial capacity. Therefore, commercial banks in Vietnam might need to improve their effective use of assets, especially when mean value of ROA gradually decreased from 2011 to 2015.

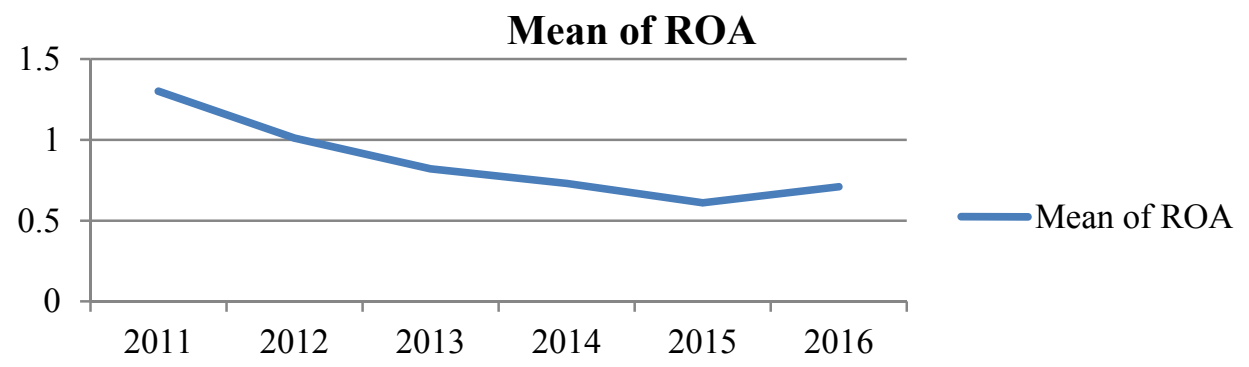

Graph 1. Mean value of ROA (\%) through years

With regard to corporate social responsibility index, the results in the table show that the maximum CSR index was 0,7 , while the minimum was 0,22 . The mean of CSRD index for the entire sample of banks over analysed period was 0,43 , indicating relatively low level of Vietnamese commercial banks' corporate social responsibility disclosure index. However, this situation has been improved through years.

\section{Mean of CSRD}

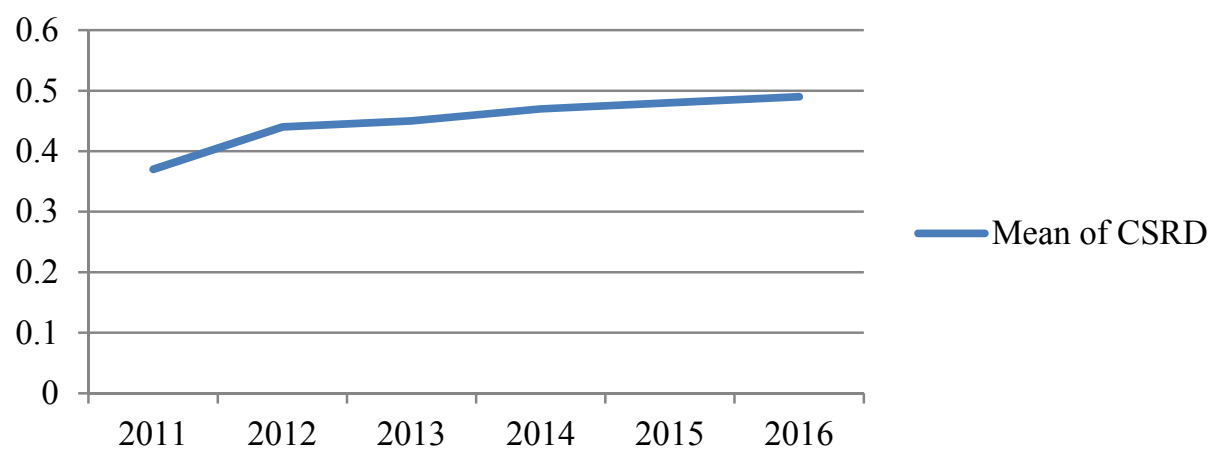

Graph 2. Mean value of CSRD through years 
Graph 2 clearly shows that the mean of CSRD of Vietnamese commercial banks has gradually increased from 2011 to 2016, which might be explained by more attention to corporate social responsibility of society after many serious pollution incidents as well as violation of labour law happened in Vietnam at the end of 2009 and 2010. More importantly, when analysing individual dimension of CSR, more and more information related to environment was published by banks leading to increase in environmental disclosure index (from 0,0625 in 2011 to 0,233 in 2016). The same pattern was also witnessed in other dimensions but less significant.

In term of control variables, bank's size ranges between 8,8439 and 10,6572 with a mean value of 9,7758 . The loan ratio fluctuates between $30,44 \%$ and $72,38 \%$, while the highest capital ratio is $23,84 \%$ and the lowest is $4,26 \%$, having a mean of $9,54 \%$. Finally, the maximum and minimum values of the overhead expenses is 1,07 and $5,79 \%$ respectively, with a mean value of $2,32 \%$.

In case of outliers, there are some observations are out at the outlier labelling rule; therefore, this research followed previous researchers such as Artiach, Lee, Nelson and Walker (2010) and Platonova, Asutay, Dixon, and Mohammad (2016) in dealing with an outlier through winsorising. Besides, according to table 3, as both standard skewness and standard kurtosis of variables are within $\pm 1,96$ and \pm 3 respectively, the data is normal distributed (Haniffa and Hudaib, 2006).

Table 3. Statistics

\begin{tabular}{ccccccc}
\hline \multicolumn{7}{c}{ Statistics } \\
\hline & ROA & CSRD & LA & EA & LTA & NEA \\
\hline Mean &, 008634 &, 433604 &, 558651 &, 095423 & 9,764118 &, 02327 \\
Median &, 007650 &, 439024 &, 567350 &, 083850 & 9,891795 &, 02600 \\
Skewness &, 957 &,- 929 &,- 346 & 1,786 &,- 296 &,- 487 \\
Kurtosis & 1,544 & 2,347 &,- 862 & 2,949 & $-1,011$ &, 650 \\
\hline
\end{tabular}

Durbin Watson value is 2,005 (Table 4), which is just little over 2 and especially ranges between $\mathrm{d}_{U}$ and $4-\mathrm{d}_{U}$ according to Durbin-Watson significant tables; therefore, autocorrelation might not be problem in this paper.

Table 4. Durbin- Watson

\begin{tabular}{cccccc}
\hline \multicolumn{6}{c}{ Model Summary $^{\mathrm{b}}$} \\
\hline Model & $\mathrm{R}$ & R Square & Adjusted R Square & Std. Error of the Estimate & Durbin-Watson \\
\hline 1 &, $462^{\mathrm{a}}$ &, 213 &, 163 &, 0041585 & 2,005 \\
\hline
\end{tabular}

a. Predictors: (Constant), CSRD, LTA, EA, LA, NEA

b. Dependent Variable: ROA

Moreover, Pearson product moment correlation coefficient showed that the highest absolute value of correlation coefficient between each of independent variable in this study was 0.637 , which was less than 0.7 (table 5); therefore, multicollinearity does not happen in this study.

Table 5. Correlation metrix

Correlations

\begin{tabular}{clcccccc}
\hline & & ROA & CSRD & LA & EA & LTA & NEA \\
\hline ROA & Pearson Correlation & 1 &,$- 372^{* *}$ &,- 035 &, $397^{* *}$ &,$- 214^{*}$ &,- 193 \\
CSRD & Pearson Correlation &,$- 372^{* *}$ & 1 &, 123 &,$- 246^{*}$ &, $254^{*}$ &, $245^{*}$ \\
LA & Pearson Correlation &,- 035 &, 123 & 1 &, 132 &,- 037 &, $230^{*}$ \\
EA & Pearson Correlation &, $397^{* *}$ &,$- 246^{*}$ &, 132 & 1 &,$- 637^{* *}$ &,- 151 \\
LTA & Pearson Correlation &,$- 214^{*}$ &, $254^{*}$ &,- 037 &,$- 637^{* *}$ & 1 &, 099 \\
NEA & Pearson Correlation &,- 193 &, $245^{*}$ &, $230^{*}$ &,- 151 &, 099 & 1 \\
\hline
\end{tabular}

**. Correlation is significant at the 0.01 level (2-tailed).

*. Correlation is significant at the 0.05 level (2-tailed). 
Importantly, the econometric result of model supports the argument in literature that corporate social responsibility disclosure index is significantly and negatively related to ROA or banks' financial performance.

Table 6. Model's result

\begin{tabular}{llll}
\multicolumn{4}{c}{ ANOVA $^{\mathrm{a}}$} \\
\hline Model & $\mathrm{F}$ & Sig. \\
\hline 1 & Regression & 4,223 &, $002^{\mathrm{b}}$
\end{tabular}

a. Dependent Variable: ROA

b. Predictors: (Constant),CSRD, LTA, EA, LA, NEA

Coefficients $^{\mathrm{a}}$

\begin{tabular}{ccccccc}
\hline \multirow{2}{*}{ Model } & \multicolumn{2}{c}{ Unstandardized Coefficients } & Standardized Coefficients & \multirow{2}{*}{ S } & \multirow{2}{*}{ Sig. } \\
\cline { 2 - 4 } & B & Std. Error & Beta & &, 025 &, 980 \\
\hline \multirow{2}{*}{ (Constant) } &, 000 &, 012 & & $-2,822$ &, 006 \\
& CSRD &,- 010 &, 003 &,- 308 &, 919 &, 361 \\
1 & LTA &, 001 &, 001 &, 120 & 2,587 &, 012 \\
& EA &, 038 &, 015 & -342 &,- 288 &, 774 \\
& LA &,- 001 &, 005 &,- 030 &,- 141 &, 888 \\
\hline
\end{tabular}

a. Dependent Variable: ROA

This finding is consistent with results in studies conducted by Brammer, Brooks and Pavelin (2006) and Surroca and Tribó (2008). However, not like other studies in which economic disadvantage or opportunity cost were often considered as main reasons why negative relationship between corporate social performance and financial performance existed in previous researches, additional requirements of the law for social responsibility while banks are in difficult situation as a result of economic slowdown during researched period might be the best explanation for this negative linkage. In particular, according to annual reports of State Bank of Vietnam from 2011 to 2015 (SBV, 2011 - 2015), economic slowdown and difficult business activities during this time leaded to slow growth of commercial banks' credit and returns declined as well. By contrast during this time, the topic of corporate social responsibility of firms has been drawing more and more concerns as a result of increase in the number of environmental and social violations. This made banks have to put more money and effort into training employees about managing environment and social risks as well as building environmental and social risk management system in banks as requirements of State bank of Vietnam. But the importance is Vietnamese banking customers, according to Quan, Thuy, Ly (2017), prefer CSR initiatives benefiting themselves or in particular, customers were attracted to banks giving them higher returns but charging lower fees on transactions. Therefore, investing money in managing environmental and social risks to facilitate sustainable development in recent years did not bring Vietnamese commercial banks' financial benefits immediately but might be in the future.

\section{Conclusions}

To be defined as "the voluntariness of enterprise in committing to comply with the regulations of labour, environment, and business activities basing on national laws, international general rules, and ensure the harmonious benefit of parties, together with sustainable development of national socio -economic." (Institute of Labour Science and Social Affairs of Vietnam, 2011), corporate social responsibility has been coming one of requirements in business. However, competitive advantages that firm can gain from disclosing CSR is still a question needed to be answer. While scholars confirming 'trade-off hypothesis' show that joining CSR practices might make firms undermine the main object of the company which is according to Friedman (1970) is maximising profit; corporate social responsibility of firms is stressed by supporters of 'social impact hypothesis', who indicate that by satisfying the needs of different group of stakeholders, firms can achieve greater effectiveness and efficiency and therefore enhance their financial performance. Also analysing the relationship between CSRD and financial performance but focusing in Vietnamese commercial banks from 2011 to 2016 , this study finds negative relationship between corporate social responsibility and Vietnamese commercial banks' 
financial performance.

The negative effect in this study might be explained by additional requirements of the law for social responsibility while banks are in difficult situation as a result of economic slowdown during researched period. Besides, perception of bank customers toward banking corporate social responsibility of Vietnam also contributed to build up this negative linkage.

There are certain limitations in this study as with all other studies. Particularly, this study only looked at annual report downloaded from banks' official websites to measure corporate social responsibility disclosure. Moreover, four dimensions of corporate social responsibility are treated equally and researched period is short and especially cover the time when Vietnam's economy was in difficult situation might affect result. Therefore, to go to conclusion that whether applying CSR truly negatively impact on Vietnamese banks' financial performance or not, further studies needed to be conducted.

\section{References}

Adeneye, Y. B., \& Ahmed, M. (2015). Corporate social responsibility and company performance. Journal of Business Studies Quarterly, 7(1), 151.

Akinpelu, Y. A., Ogunbi, O. J., Olaniran, Y. A., \& Ogunseye, T. O. (2013). Corporate social responsibility activities disclosure by commercial banks in nigeria. European Journal of Business and Management, 5(7), 173-185.

Arshad, R., Othman, S., \& Othman, R. (2012). Islamic corporate social responsibility, corporate reputation and performance. World Academy of Science, Engineering and Technology, 64(4), 1070-1074.

Artiach, T., Lee, D., Nelson, D., \& Walker, J. (2010). The determinants of corporate sustainability performance. Accounting \& Finance, 50(1), 31-51. https://doi.org/10.1111/j.1467-629x.2009.00315.x

Athanasoglou, P. P., Brissimis, S. N., \& Delis, M. D. (2008). Bank-specific, industry-specific and macroeconomic determinants of bank profitability. Journal of international financial Markets, Institutions and Money, 18(2), 121-136. https://doi.org/10.1016/j.intfin.2006.07.001

Aupperle, K. E., Carroll, A. B., \& Hatfield, J. D. (1985). An empirical examination of the relationship between corporate social responsibility and profitability. Academy of management Journal, 28(2), 446-463. https://doi.org/10.2307/256210

Barnett, M. L., \& Salomon, R. M. (2012). Does it pay to be really good? Addressing the shape of the relationship between social and financial performance. Strategic Management Journal, 33, 1304-1320. https://doi.org/10.1002/smj.1980

Belal, A. R. (2001). A study of corporate social disclosures in Bangladesh. Managerial Auditing Journal, 16(5), 274-289. https://doi.org/10.1108/02686900110392922

Bikker, J. A., \& Hu, H. (2012). Cyclical patterns in profits, provisioning and lending of banks and procyclicality of the new Basel capital requirements. PSL Quarterly Review, 55, 221.

Bowman, E. H., \& Haire, M. (1975). A strategic posture toward corporate social responsibility. California Management Review, 18, 49-58. https://doi.org/10.2307/41164638

Brammer, S., Brooks, C., \& Pavelin, S. (2006). Corporate social performance and stock returns: UK evidence from disaggregate measures. Financial management, 35(3), 97-116. https://doi.org/10.2139/ssrn.739587

Brine, M., Brown, R., \& Hackett, G. (2007). Corporate social responsibility and financial performance in the Australian context. Economic Round-up, (Autumn 2007), 47.

Chen, H. and Wang, X. (2011). Corporate social responsibility and corporate financial performance in China: An empirical research from Chinese firms. Corporate governance, 11 (4), 361-370. https://doi.org/10.1108/14720701111159217

Cheung, P., \& Mak, W. (2010). The relation between corporate social responsibility disclosure and financial performance: Evidence from the commercial banking industry (Doctoral dissertation, Beedie School of Business-Segal Graduate School).

Cochran, P. L., \& Wood, R. A. (1984). Corporate social responsibility and financial performance. Academy of management Journal, 27(1), 42-56.

Crane, A., Matten, D., \& Spence, L. J. (2008). Corporate Social Responsibility Readings and cases in a global context. London and New York: Routledge. 
Dodd, E. M. (1932). For whom are corporate managers trustees?. Harvard law review, 45(7), 1145-1163. https://doi.org/10.2307/1331697

Field, A. P. (2009). Discovering statistics using SPSS: And sex and drugs and rock' ' $n$ ' roll (3rd ed.). Los Angeles, [Calif.]; London: SAGE.

Francis, M. E. (2013). Determinants of commercial bank profitability in Sub-Saharan Africa. International journal of economics and finance, 5(9), 134. https://doi.org/10.5539/ijef.v5n9p134

Freedman, M., \& Jaggi, B. (1986). An analysis of the impact of corporate pollution disclosures included in annual financial statements on investors' decisions. Advances in public interest accounting, 1(2), 193-212.

Friedman, M. (1970). The social responsibility of business is to increase its profits. New York Times Magazing, 32-33(122), 126. https://doi.org/10.1007/978-3-540-70818-6_14

García-Herrero, A., Gavilá, S., \& Santabárbara, D. (2009). What explains the low profitability of Chinese banks?. Journal of Banking \& Finance, 33(11), 2080-2092. https://doi.org/10.2139/ssrn.1514291

Greening DW, Turban DB. (2000). Corporate social performance as a competitive advantage in attracting a quality workforce. Business and Society, 39(3), 254-280. https://doi.org/10.1177/000765030003900302

Griffin, J. J., \& Mahon, J. F. (1997). The corporate social performance and corporate financial performance debate: Twenty-five years of incomparable research. Business \& society, 36(1), 5-31. https://doi.org/10.1177/000765039703600102

Grigoris Giannarakis, George Konteos, Eleni Zafeiriou and Xanthi Partalidou (2016). The impact of corporate social responsibility on financial performance. Investment Management and Financial Innovations (open-access), 13(3-1). https://doi.org/10.21511/imfi.13(3-1).2016.03

Growe, G., DeBruine, M., Lee, J. Y., \& Tudón Maldonado, J. F. (2014). The profitability and performance measurement of US regional banks using the predictive focus of the "fundamental analysis research". In Advances in Management Accounting(pp. 189-237). Emerald Group Publishing Limited. https://doi.org/10.1108/s1474-787120140000024006

Gujarati, D. (1999). Essentials of econometrics (2nd ed.). London: McGraw-Hill.

Gujarati, D. (2003). Basic econometrics (4th, international ed.). Boston, [Mass.]; London: McGraw-Hill.

Haniffa, R., \& Hudaib, M. (2006). Corporate governance structure and performance of Malaysian listed companies. Journal of Business Finance \& Accounting, 33(7-8), 1034-1062.

Haniffa, R., \& Hudaib, M. (2007). Exploring the ethical identity of Islamic banks via communication in annual reports. Journal of Business Ethics, 76(1), 97-116. https://doi.org/10.1007/s10551-006-9272-5

Hieu, P. D. (2011). Corporate social responsibility: A study on awareness of managers and consumers in Vietnam. Journal of Accounting and Taxation, 3(8), 158. https://doi.org/10.5897/jat11.016

Hillman, A. J., Kein, G. D., \& Luce, R. A. (2001). Board composition and stakeholder performance: Do stakeholder directors make a difference? Business \& Society, 40(3), 295-314. https://doi.org/10.1177/000765030104000304

Huizinga, H. (2000). Financial structure and bank profitability(Vol. 2430). World Bank Publications.

Institute of Labour Science and Social Affairs of Vietnam (2011) Research on labour law and policies on corporate social responsibility. Retrieved from http://www.globalcompactvietnam.org/upload/attach/CSR\% 20and\%20Labour\%20in\%20Vietnam_EN.pdf

Jaggi, B., \& Freedman, M. (1982). An analysis of the informational content of pollution disclosures. Financial Review, 17(3), 142-152. https://doi.org/10.1111/j.1540-6288.1982.tb00497.x

Jensen M. (2002). Value maximization, stakeholder theory, and the corporate objective function. Business Ethics Quarterly, 12, 235-256. https://doi.org/10.2307/3857812

Kennedy, P. (2008). A guide to econometrics (6th ed.). Malden, Mass; Oxford: Blackwell.

Kosmidou, K. (2008). The determinants of banks' profits in Greece during the period of EU financial integration. Managerial Finance, 34(3), 146-159. https://doi.org/10.1108/03074350810848036

Lipunga, A. M. (2013). Corporate social responsibility reporting by commercial banks in annual reports: Evidence from Malawi. International Journal of Business and Social Research, 3(9).

Mahoney, L., \& Roberts, R. W. (2007, September). Corporate social performance, financial performance and 
institutional ownership in Canadian firms. In Accounting forum (Vol. 31, No. 3, pp. 233-253). Elsevier. https://doi.org/10.1016/j.accfor.2007.05.001

Makni, R., Francoeur, C., \& Bellavance, F. (2009). Causality between corporate social performance and financial performance: Evidence from Canadian firms. Journal of Business Ethics, 89(3), 409-422. https://doi.org/10.1007/s10551-008-0007-7

Mamatzakis, E., \& Remoundos, P. (2003). Determinants of Greek commercial banks, 1989-2000. Spoudai, 53(1), 84-94.

McWilliams, A., \& Siegel, D. (2000). Corporate social responsibility and financial performance. Strategic Management Journal, 21(5), 603-609.

Moskowitz, M. (1972). Choosing socially responsible stocks. Business and Society Review, 1(1), 71-75.

Nguyen, B. T. N., Tran, H. T. T., Le, O. H., Nguyen, P. T., Trinh, T. H., \& Le, V. (2015). Association between Corporate Social Responsibility Disclosures and Firm Value-Empirical Evidence from Vietnam. International Journal of Accounting and Financial Reporting, 5(1), 212-228. https://doi.org/10.5296/ijafr.v5i1.7394

Nollet, J., Filis, G., \& Mitrokostas, E. (2016). Corporate social responsibility and financial performance: A non-linear and disaggregated approach. Economic Modelling, 52, 400-407. https://doi.org/10.1016/j.econmod.2015.09.019

Olson, D., \& Zoubi, T. A. (2011). Efficiency and bank profitability in MENA countries. Emerging markets review, 12(2), 94-110. https://doi.org/10.1016/j.ememar.2011.02.003

Pallant, J. (2013). SPSS survival manual: A step by step guide to data analysis using IBM SPSS (5th ed.). Maidenhead: McGraw-Hill.

Pan, X., Sha, J., Zhang, H., \& Ke, W. (2014). Relationship between corporate social responsibility and financial performance in the mineral Industry: Evidence from Chinese mineral firms. Sustainability, 6(7), 4077-4101. https://doi.org/10.3390/su6074077

Platonova, E., Asutay, M., Dixon, R., \& Mohammad, S. (2016). The impact of corporate social responsibility disclosure on financial performance: evidence from the GCC Islamic Banking Sector. Journal of Business Ethics, 1-21. https://doi.org/10.1007/s10551-016-3229-0

Preston, L. E., \& O'bannon, D. P. (1997). The corporate social-financial performance relationship: A typology and analysis. Business \& Society, 36(4), 419-429.

Quan, N. T., Thuy, T. L., \& Ly. N. T. H. (2017) Perception of Bank Customers towards Banking Corporate Social Responsibility in Vietnam. International Research Journal of Finance and Economics, 161, 81- 95.

Saleh, M. (2009). Corporate social responsibility disclosure in an emerging market: a longitudinal analysis approach. International Business Research, 2(1), 131. https://doi.org/10.5539/ibr.v2n1p131

Saunders, M., Lewis, P., \& Thornhill, A. (2007). Research methods for business students (4th ed.). Harlow: Financial Times Prentice Hall.

Simpson, W. G., \& Kohers, T. (2002). The link between corporate social and financial performance: Evidence from the banking industry. Journal of business ethics, 35(2), 97-109.

Soana, M. G. (2011). The relationship between corporate social performance and corporate financial performance in the banking sector. Journal of Business Ethics, 104(1), 133-148. https://doi.org/10.1007/s10551-011-0894-x

Staikouras, C. K., \& Wood, G. E. (2004). The determinants of European bank profitability. International Business \& Economics Research Journal (IBER), 3(6). https://doi.org/10.19030/iber.v3i6.3699

Stanwick, P. A., \& Stanwick, S. D. (1998). The relationship between corporate social performance, and organizational size, financial performance, and environmental performance: An empirical examination. Journal of business ethics, 17(2), 195-204.

State Bank of Vietnam (SBV) (2011-2015). Annual reports. Retrieved from https://www.sbv.gov.vn/web center $/$ portal $/$ en $/$ home $/ \mathrm{rm} /$ public/nreport?centerWidth $=80 \% 25 \&$ leftWidth $=20 \% 25 \& \mathrm{p}=1 \&$ rightWidth $=0 \% 25$ \&showFooter $=$ false\&showHeader=false\&_adf.ctrl-state $=a 6062 n 4 b c \_120 \& \_a f r L o o p=173666473924000$

Surroca, J., \& Tribó, J. A. (2008). Managerial entrenchment and corporate social performance. Journal of Business Finance \& Accounting, 35(5-6), 748-789. https://doi.org/10.1111/j.1468-5957.2008.02090.x 
Surroca, J., Tribó, J. A., \& Waddock, S. (2010). Corporate responsibility and financial performance: The role of intangible resources. Strategic management journal, 31(5), 463-490. https://doi.org/10.1002/smj.820

Tan, Y., \& Floros, C. (2012). Bank profitability and inflation: the case of China. Journal of Economic Studies, 39(6), 675-696. https://doi.org/10.1108/01443581211274610

Taskin, D. (2015). The Relationship between CSR and Banks' Financial Performance: Evidence from Turkey. Journal of Yaşar University, 10(39), 21-30. https://doi.org/10.19168/jyu.97694

Tjia, O., \& Setiawati, L. (2012). Effect of CSR disclosure to value of the firm: Study for banking industry in Indonesia. World Journal of Social Science, 2(6).

Trang, H. N. T., \& Yekini, L. S. (2014). Investigating the link between CSR and financial performance: Evidence from Vietnamese listed companies. British Journal of Arts and Social Sciences, 17(1), 85-101.

Trujillo-Ponce, A. (2013). What determines the profitability of banks? Evidence from Spain. Accounting \& Finance, 53(2), 561-586. https://doi.org/10.1111/j.1467-629x.2011.00466.x

Ullmann, A. A. (1985). Data in search of a theory: A critical examination of the relationships among social performance, social disclosure, and economic performance of US firms. Academy of management review, 10(3), 540-557. https://doi.org/10.5465/amr.1985.4278989

UNIDO (2013) Helping Vietnamese SMEs to dapt and Adopt CSR for Improved Linkages in Global Supply Chains in Sustainable Production. Retrieved from http://www.globalcompactvietnam.org/upload/attach/ CSR\%20EOA\%20Survey\%20complete\%20UNIDO\%202013\%20TNS.pdf

UNIDO. (2010). Báo cáo điều tra ban đầu về nhận thức, hiểu biết và thực hiện trách nhiêm xã hội của các doanh nghiêp vì̀a và nhỏ Việt Nam. Retrieved from http://csr-vietnam.org/en/Downloads.html

Waddock, S. A., \& Graves, S. B. (1997). The corporate social performance-financial performance link. Strategic Management Journal, 303-319. https://doi.org/10.1002/(sici)1097-0266(199704)18:4\%3C303::aid-smj 869\%3E3.3.co;2-7

Wang, H., Choi, J., \& Li, J. (2008). Too little or too much? Untangling the relationship between corporate philanthropy and firm financial performance. Organization Science, 19(1), 143-159. https://doi.org/10.1287/orsc.1070.0271

Weber, R. P. (1990). Basic content analysis (No. 49). Sage.

\section{Appendix}

Appendix 1: Dimensions of CSRD

\begin{tabular}{|c|c|c|c|}
\hline $\begin{array}{c}\text { A. Disclosures of } \\
\text { community involvement }\end{array}$ & $\begin{array}{l}\text { B. Disclosures of } \\
\text { human resource }\end{array}$ & $\begin{array}{l}\text { C. Disclosures of } \\
\text { Environment }\end{array}$ & $\begin{array}{l}\text { D. Disclosures of product and } \\
\text { customers }\end{array}$ \\
\hline Donation to public health & $\begin{array}{l}\text { Training, seminar } \\
\text { and workshop }\end{array}$ & $\begin{array}{l}\text { Environmental standard } \\
\text { consideration for } \\
\text { extending loan }\end{array}$ & Customer satisfaction \\
\hline $\begin{array}{l}\text { Sponsorship to arts, sports } \\
\text { and culture }\end{array}$ & $\begin{array}{c}\text { Credit facilities } \\
\text { under various loan } \\
\text { policies }\end{array}$ & $\begin{array}{c}\text { Promoting } \\
\text { environmental awareness }\end{array}$ & Customer complaints \\
\hline Scholarship programs & $\begin{array}{l}\text { Employee } \\
\text { remuneration }\end{array}$ & $\begin{array}{l}\text { Tree plantation } \\
\text { (Greening) }\end{array}$ & $\begin{array}{l}\text { Specific consumer relations } \\
\text { (over and beyond "our duty to } \\
\text { the customer) }\end{array}$ \\
\hline $\begin{array}{l}\text { Assistance to vulnerable } \\
\text { groups (women, } \\
\text { orphanage, disabled etc) }\end{array}$ & $\begin{array}{l}\text { Employee family } \\
\text { welfare }\end{array}$ & $\begin{array}{l}\text { Smoking free area in } \\
\text { bank premises }\end{array}$ & $\begin{array}{l}\text { Provision for disabled, aged etc } \\
\text { customers }\end{array}$ \\
\hline $\begin{array}{l}\text { Donation to the education, } \\
\text { training and other } \\
\text { organizations }\end{array}$ & $\begin{array}{l}\text { Good working } \\
\text { environment }\end{array}$ & $\begin{array}{l}\text { Environmental } \\
\text { protection }\end{array}$ & $\begin{array}{l}\text { Provision for difficult to reach } \\
\text { customers }\end{array}$ \\
\hline Branch opening & $\begin{array}{c}\text { Individual and } \\
\text { Branch performance } \\
\text { appraisal }\end{array}$ & Sustainability & $\begin{array}{l}\text { SME (Small and medium } \\
\text { enterprise) banking }\end{array}$ \\
\hline
\end{tabular}




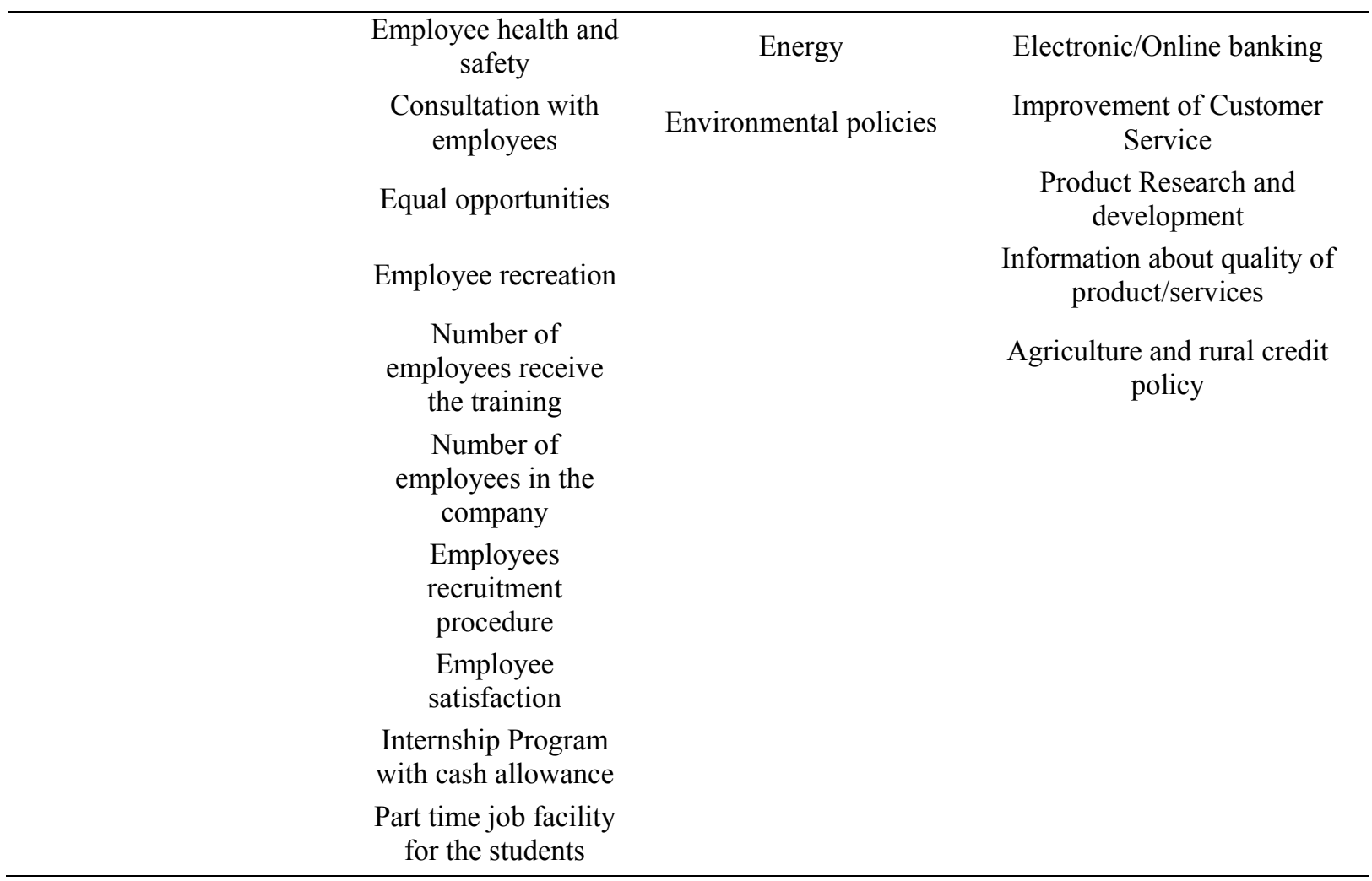

Source: Lipunga, (2013).

\section{Copyrights}

Copyright for this article is retained by the author(s), with first publication rights granted to the journal.

This is an open-access article distributed under the terms and conditions of the Creative Commons Attribution license (http://creativecommons.org/licenses/by/4.0/). 